\title{
Are Critical Thinking Tendencies of the Physical Education Teacher Candidates Differ from Mathematics and Literature?
}

\author{
Fatih ÖZGÜL* \\ Associate Professor, Giresun University, Sport Science Faculty, Giresun, Turkey.
}

*Corresponding Author: Fatih ÖZGÜL, Associate Professor, Giresun University, Sport Science Faculty, Giresun, Turkey.

\begin{abstract}
The aim of this study is to examine whether the critical thinking tendencies of the Physical Education teacher candidates differ from the Mathematics and Literature teacher candidates.This research was designed in a scanning model and conducted with the participation of 300 volunteer teacher candidates who were determined according to the stratified sampling method. The Critical Thinking Scale developed by Karall (2014) was used to collect data in the research. Scale consists of 2 sub-dimensions as; Skill and Value, and a total of 21 items. SPSS (ver.23.00) package program was used to evaluate the data. Since the data conformed to normal distribution (Kolmogorov-Smirnov), Anova, Tuckey and t test were used for analyzing the data and significance level was taken as .05. The total and sub-dimension scores of the teacher candidates obtained from the scale were compared according to the departments and statistically significant differences were found between them $(p<0.05)$. Especially, the differences between the physical education and sports teaching and mathematics teacher candidates were found to be significant in favor of the Physical Education and Sports teacher candidates $(p<0.05)$.There was no significant difference between the physical education and sports teaching and literature teacher candidates $(p>0.05)$.
\end{abstract}

Keywords: Critical Thinking, Physical Education, Teacher Candidates.

\section{INTRODUCTION}

How learning and thinking takes place in the educational environment and the practices that can be done in this direction are among the main agenda items in educational research.In this context, being aware of the learning styles of students regarding learning and thinking processes and revealing their critical thinking understanding is an important step towards increasing their academic success. It is known that students teach according to their own learning (Beşoluk \& Önder, 2010; Bybee, 2010 Zhang \&Lambert, 2008).It is important for teacher candidates to know the characteristics of education that may differ individually such as critical thinking, to be aware of the importance of these characteristics and to have knowledge and skills in educational arrangements by being affected by their personal characteristics as little as possible intheir professional lives.Fisher (1995) defined critical thinking as the process of reaching a balanced judgment after examining an individual's past lives, information, different ideas and opinions.Critical thinking is a skill that can be taught and developed. In addition, the concept of disposition, which means individuals' willingness to think critically, is another important component in this way of thinking. A critical thinker has a wide variety of skills, such as asking an effective question, focusing on a question or problem, assimilating basic concepts of the unit of knowledge he / she thinks, making inferences and evaluating them, making effective observations, and being careful against assumptions (Ennis, 2011). Critical thinking is a complex concept that has been tried to be defined by many researchers and its conceptual context varies according to the defined subject (Ruff, 2005). When the literature is examined; some studies conducted with teacher candidates from different departments and they stated that the critical thinking levels of the candidates were low or medium (Bulut \&Ocak, 2017; Kartal, 2012; Türnüklü \& Yeşildere, 2005; Can \& Kaymakc1, 2015; Tümkaya, 2011;Wangensteen et al., 2010; Kawashima \& Shiomi, 2007; Loken, 2005; Ricketts\& Rudd, 2004; McBride, Xiang \&Wittenburg, 2002; LeaverDunn, Harrelson, Martin \&Wyatt, 2002; Thompson, 2001; Rodriquez, 2000).However, studies in which physical education and sports teacher candidates' tendencies of critical thinking are included in the sample group are quite insufficient in number. For this reason this research is very important by evaluating physical education and sports teachers who want to train students with critical thinking 
Are Critical Thinking Tendencies of the Physical Education Teacher Candidates Differ from Mathematics and Literature?

skills. The aim of this study is to examine whether the critical thinking tendencies of the Physical Education teacher candidates differ from the Mathematics and Literature teacher candidates.

\subsection{Research Problems}

- Critical Thinking Tendencies of Physical Education Teacher Candidates differ from Mathematics and Literature Teacher Candidates?

- Do the teacher candidates' critical thinking tendencies differ by age?

- Do the teacher candidates' critical thinking tendencies differ by gender?

- Do the teacher candidates' critical thinking tendencies differ by class?

\section{METHOD}

This research was conducted using the relational screening model.Studies aimed at expressing an existing situation as it is in their own conditions are defined as a screening model. Relational scanning model can be defined as a scanning approach that aims to determine the existence of change between two or more variables (Büyüköztürk, 2018).Stratified purposeful sampling method was used in the study. The reason for choosing this sampling method is that a total of 300 students, 25 students from each class who voluntarily participated in the study, from departments where bodily-kinesthetic intelligence, verbal-linguistic intelligence and logical-mathematical intelligence areas are at the forefront. Table 1 shows the distribution of teacher candidates according to their grade level, gender, department and age.

Table1. Distribution of Teacher Candidates by Grade Level, Gender, Department and Age

\begin{tabular}{|l|l|l|}
\hline Grade Level & f & $\%$ \\
\hline 1 st. Class & 20 & 6,6 \\
\hline 2 nd. Class & 71 & 23,6 \\
\hline 3 rd. Class & 140 & 46,5 \\
\hline 4 th. Class & 69 & 22,9 \\
\hline Gender & $\mathbf{f}$ & $\%$ \\
\hline Woman & 148 & 49,2 \\
\hline Man & 152 & 50,5 \\
\hline Department & $\mathbf{f}$ & $\%$ \\
\hline Physical Education and Sports & 98 & 32,6 \\
\hline Literature & 102 & 33,9 \\
\hline Mathematics & 100 & 33,2 \\
\hline Age & $\mathbf{f}$ & $\%$ \\
\hline $18-20$ years & 62 & 20,6 \\
\hline $21-23$ years & 175 & 58,1 \\
\hline $24-26$ years & 49 & 16,3 \\
\hline $27-30$ years & 14 & 4,7 \\
\hline
\end{tabular}

According to the Table 1; $49.2 \%$ of the teacher candidates are women and 50.5\% are men. $20.6 \%$ of the teacher candidates were $18-20$ years old, $58.1 \%$ were $21-23$ years old, $16.3 \%$ were $24-26$ years old, and $4.7 \%$ were $27-30$ years old. Of the teacher candidates, $6.6 \%$ are 1 st grade, $23.6 \%$ are 2nd grade, $46.5 \%$ are 3 rd grade and $22.9 \%$ are 4 th grade. $32.6 \%$ of the teacher candidates are Physical Education and Sports Teaching, 33.9\% Literature Teaching, 33.2\% Mathematics Teaching department students.

\subsection{Data Collecting Tool}

The Critical Thinking Disposition Scale developed by Karalı (2012) was used as data collection tool in the study. The scale consists of 2 sub-dimensions as "Skill" and "Value" and a total of 21 items graded in a 5-point Likert type.The Cronbach Alpha reliability coefficient of the scale was found to be .794 .

\subsection{Data Analysis}

SPSS (ver.23.00) package program was used to evaluate the data. Since the data were compatible with normal distribution (Kolmogorov-Smirnov), for analyzing the data Anova, Tuckey and tests were used and the significance level was taken as .05. 
Are Critical Thinking Tendencies of the Physical Education Teacher Candidates Differ from Mathematics and Literature?

\section{RESULTS}

Table2. Comparison of teacher candidates' total scale scores and sub-dimension scores according to their departments

\begin{tabular}{|c|c|c|c|c|c|c|c|}
\hline Scale & Department & $\mathbf{N}$ & Mean & Std. Dev. & Min & Max & Result \\
\hline \multirow{3}{*}{ Total } & Physical Education and Sports & 98 & 72,54 & 9.08 & 41,00 & 98,00 & \multirow{3}{*}{$\begin{array}{l}F=6.079 \\
* p=0.003\end{array}$} \\
\hline & Literature & 102 & 69,51 & 9,62 & 43,00 & 102,00 & \\
\hline & Mathematics & 100 & 66,96 & 14,34 & 31,00 & 95,00 & \\
\hline \multirow{3}{*}{ Skill } & Physical Education and Sports & 98 & 43,31 & 5,74 & 23,00 & 60,00 & \multirow{3}{*}{$\begin{array}{l}F=12.918 \\
* p=0.000\end{array}$} \\
\hline & Literature & 102 & 42,61 & 5,60 & 28,00 & 60,00 & \\
\hline & Mathematics & 100 & 38,76 & 8,65 & 16,00 & 55,00 & \\
\hline \multirow{3}{*}{ Value } & Physical Education and Sports & 98 & 29,22 & 4,80 & 18,00 & 40,00 & \multirow{3}{*}{$\begin{array}{l}F=4.314 \\
* \mathbf{p}=0.014\end{array}$} \\
\hline & Literature & 102 & 26,90 & 5,36 & 15,00 & 42,00 & \\
\hline & Mathematics & 100 & 28,20 & 6,50 & 12,00 & 41,00 & \\
\hline
\end{tabular}

*p $<0.05$ significant

When Table 2 is examined; The total and sub-dimension scores obtained from the scale were compared by departments and statistically significant differences were found between them $(p<0.05)$. When the groups are compared in pairs; According to the mean scores obtained from the scale, a significant difference was found between physical education and sports teaching and mathematics teaching $(\mathrm{p}<0.05)$, while no significant difference was found between the others $(\mathrm{p}>0.05)$. This difference is in favor of the Department of Physical Education and Sports Teaching. Students of the Department of Physical Education and Sports Teaching have a good level of Critical Thinking Skills according to their average scores.

According to the skill sub-dimension average scores; significant differences were found between Physical Education and Sports Teaching and Mathematics Teaching and Mathematics Teaching and Literature Teaching departments( $\mathrm{p}<0.05)$, but no significant difference was found between the others (p> 0.05). According to this, Physical Education and Sports Teaching Department's candidates have higher score averages than the others.

According to the value sub-dimension scores; significant differences were found between Physical Education and Sports Teaching and Literature Teaching departments( $\mathrm{p}<0.05)$, but no significant difference was found between the others ( $p>0.05$ ). According to this, Physical Education and Sports Teaching Department's candidates have higher score averages than Literature Teaching Departments' candidates.

Table3. Comparison of teacher candidates' total scale scores and sub-dimension scores according to their ages

\begin{tabular}{|c|c|c|c|c|c|c|c|}
\hline Scale & Age Groups & $\mathbf{N}$ & Mean & Std. Dev. & Min & Max & Result \\
\hline \multirow{4}{*}{ Total } & $18-20$ years & 62 & 67,27 & 11,28 & 34,00 & 88,00 & \multirow{4}{*}{$\begin{array}{l}F=1.736 \\
p=0.160\end{array}$} \\
\hline & $21-23$ years & 175 & 70,50 & 10,75 & 31,00 & 102,00 & \\
\hline & 24-26 years & 49 & 70,57 & 12,81 & 43,00 & 95,00 & \\
\hline & $27-30$ years & 14 & 66,28 & 14,67 & 36,00 & 85,00 & \\
\hline \multirow{4}{*}{ Skill } & 18-20 years & 62 & 40,30 & 7,46 & 18,00 & 54,00 & \multirow{4}{*}{$\begin{array}{l}F=2.426 \\
p=0.066\end{array}$} \\
\hline & $21-23$ years & 175 & 42,28 & 6,54 & 16,00 & 60,00 & \\
\hline & 24-26 years & 49 & 41,55 & 7,91 & 23,00 & 55,00 & \\
\hline & $27-30$ years & 14 & 38,07 & 7,77 & 21,00 & 49,00 & \\
\hline \multirow{5}{*}{ Value } & 18-20 years & 62 & 26,96 & 5,38 & 12,00 & 38,00 & \multirow{5}{*}{$\begin{array}{l}F=1.288 \\
p=0.279\end{array}$} \\
\hline & $21-23$ years & 175 & 28,22 & 5,49 & 13,00 & 42,00 & \\
\hline & 24-26 years & 49 & 29,02 & 6,12 & 17,00 & 41,00 & \\
\hline & $27-30$ years & 14 & 28,21 & 7,19 & 15,00 & 38,00 & \\
\hline & Total & 300 & 28,09 & 5,66 & 12,00 & 42,00 & \\
\hline
\end{tabular}

According to the table, no significant difference was found between the scale total and subscale mean scores of the teacher candidates according to their ages ( $p>0.05)$.

Table4. Comparison of teacher candidates' total scale scores and sub-dimension scores according to their gender

\begin{tabular}{|l|l|l|l|l|l|l|l|}
\hline Scale & Gender & $\mathbf{N}$ & Mean & Std. Dev. & Min & Max & Result \\
\hline Total & Woman & 148 & 69,31 & 11,00 & 31,00 & 102,00 & $\mathrm{t}=0.500$ \\
\hline
\end{tabular}


Are Critical Thinking Tendencies of the Physical Education Teacher Candidates Differ from Mathematics and Literature?

\begin{tabular}{|c|c|c|c|c|c|c|c|}
\hline & Man & 152 & 69,98 & 11,90 & 35,00 & 98,00 & $\mathrm{p}=0.345$ \\
\hline \multirow{2}{*}{ Skill } & Woman & 148 & 41,70 & 6,92 & 16,00 & 60,00 & \multirow{2}{*}{$\begin{array}{l}\mathrm{t}=0.344 \\
\mathrm{p}=0.722\end{array}$} \\
\hline & Man & 152 & 41,42 & 7,25 & 18,00 & 60,00 & \\
\hline \multirow{3}{*}{ Value } & Woman & 148 & 27,61 & 5,61 & 12,00 & 42,00 & \multirow{3}{*}{$\begin{array}{l}\mathrm{t}=1.445 \\
\mathrm{p}=0.818\end{array}$} \\
\hline & Man & 152 & 28,55 & 5,70 & 15,00 & 41,00 & \\
\hline & Total & 300 & 28,09 & 5,66 & 12,00 & 42,00 & \\
\hline
\end{tabular}

When Table 4 is examined, no significant difference found between teacher candidates' total scale scores, sub-dimension scores and gender.

Table5. Comparison of teacher candidates' total scale scores and sub-dimension scores according to their grade level.

\begin{tabular}{|c|c|c|c|c|c|c|c|}
\hline Scale & Grade Level & $\mathbf{N}$ & Mean & Std. Dev. & Min & Max & Result \\
\hline \multirow[t]{4}{*}{ Total } & 1 st. Class & 20 & 64,74 & 11,06 & 33,00 & 87,00 & \multirow{4}{*}{$\begin{array}{l}F=1.691 \\
p=0.179\end{array}$} \\
\hline & 2 nd. Class & 71 & 66,50 & 10,81 & 30,00 & 98,00 & \\
\hline & 3 rd. Class & 140 & 65,63 & 11,71 & 41,00 & 94,00 & \\
\hline & 4 th. Class & 69 & 66,12 & 13,92 & 34,00 & 86,00 & \\
\hline \multirow[t]{4}{*}{ Skill } & 1 st. Class & 20 & 37,61 & 7,12 & 17,00 & 55,00 & \multirow{4}{*}{$\begin{array}{l}\mathrm{F}=2.379 \\
\mathrm{p}=0.182\end{array}$} \\
\hline & 2 nd. Class & 71 & 38,63 & 6,70 & 15,00 & 61,00 & \\
\hline & 3 rd. Class & 140 & 41,43 & 7,81 & 22,00 & 56,00 & \\
\hline & 4 th. Class & 69 & 38,72 & 7,64 & 20,00 & 50,00 & \\
\hline \multirow[t]{5}{*}{ Value } & 1 st. Class & 20 & 28,14 & 5,28 & 13,00 & 39,00 & \multirow{5}{*}{$\begin{array}{l}\mathrm{F}=2.021 \\
\mathrm{p}=0.217\end{array}$} \\
\hline & 2 nd. Class & 71 & 28,78 & 5,69 & 14,00 & 43,00 & \\
\hline & 3 rd. Class & 140 & 30,12 & 6,42 & 18,00 & 42,00 & \\
\hline & 4 th. Class & 69 & 28,94 & 7,09 & 16,00 & 39,00 & \\
\hline & Total & 300 & 28,59 & 5,26 & 13,00 & 43,00 & \\
\hline
\end{tabular}

When Table 5 is examined, there were no significant differences between the grade level and total scale - sub-dimension scores of the teacher candidates ( $p>0.05)$.

\section{DisCuSSION \& CONCLUSION}

In this research, it was aimed to examine the critical thinking tendencies of teacher candidates studying in different departments of Cumhuriyet University according to various variables such as department, gender, age and grade level.In order to answer the sub-problems determined in line with this purpose, a total of 300 teacher candidates included in the study were directed to the critical thinking scale developed by Karalı (2012) and analyzes were conducted on the average scores obtained by the teacher candidates from this scale.Descriptive statistics to determine the critical thinking tendencies of teacher candidates participating in this study show that the average scores are above the middle level.Although some of the studies in the literature are similar to the results obtained from this research there are non similar researches (Ocak, Eymir \& Ocak, 2016; Kuvaç \& Koç, 2014; Can \& Kaymakç1, 2015). The fact that different results were obtained from this study in studies conducted with the same or similar measurement tools in the literature supports the claim that culture and environment have an effect on the results obtained regarding critical thinking (Floyd, 2011).

In some of the studies in the literature examining the critical thinking dispositions of teacher candidates according to the department variable, the students of the Department of Physical Education and Sports Teaching were included in the sample. Significant differences were found between physical education and sports teaching and mathematics teaching $(p<0.05)$, teacher candidates in this research. This difference is in favor of the Department of Physical Education and Sports Teaching. So, Physical Education and Sports Teaching teacher candidates have a good level of Critical Thinking Skills than Mathematics Teaching teacher candidates according to the total scores obtained from the scale. According to the value sub-dimension scores; significant differences were found between Physical Education and Sports Teaching and Literature Teaching teacher candidates $(\mathrm{p}<0.05)$. According to the skill sub-dimension average scoresobtained from the scale; significant differences were found between Physical Education and Sports Teaching and Mathematics Teaching and Mathematics Teaching and Literature Teaching departments( $\mathrm{p}<0.05)$. Physical Education and Sports Teaching teacher candidates and Mathematics Teaching teacher candidates have higher scores than Literature Teaching teacher candidates. According to this, Physical Education and Sports Teaching Department's candidates have higher score averages than Literature Teaching Departments' 
candidates. In the literature, there are similar or contradictory studies in which the critical thinking tendencies of teacher candidates differ significantly according to the department variable (Kutluca, Yılmaz \& İbiş, 2018; Alkın, Tunca \&Ulubey, 2014; Şenlik, Balkan \& Aycan, 2011).

When the age groups of the teacher candidates is examined in the study; no significant difference was found between the scale total and subscale mean scores of the teacher candidates according to their ages ( $p>0.05$ ). This result is supported with some similar studies in the literature (Güngör, 2016; Arslan ve Uslu, 2014).Based on this, it can be stated according to this research that critical thinking disposition is not dependent on age.

When the gender variable is examined in the study, no significant difference found between teacher candidates' total scale scores, sub-dimension scores and gender ( $p>0.05)$. Kartal, 2012; Sağlam \& Büyükuysal, 2013; Memduhoğlu \& Keleş, 2016; Tekin, Aslan \& Yağız, 2016; are the studies supporting or not supporting this result in the literature. From this point of view it can be stated that Critical thinking is not related to gender.

Also when the grade levels of the teacher candidates is examined in the study, there were no significant differences between the grade level and total scale - sub-dimension scores of the teacher candidates $(p>0.05)$. It can be evaluated that critical thinking disposition is not only related to biological variables such as age and gender, but also has a subjective context related to the life and experiences of individuals and the processes of making sense of these experienceswith the grade level variable.

Based on the results of the research, it can be suggested that the prospective teachers should create an environment that enables and develops critical thinking in undergraduate courses, and that the courses should be in a way that provides analytical thinking, arouse curiosity and establish self-confidence, and should be taught. This research is limited to prospective physical education and sports and mathematics and literature teachers. In support of this research, qualitative and mixed design studies can be designed with different teacher candidates.In this study, finding that the critical thinking disposition in favor of physical education and sports teachers is higher than the mathematics and literature department teacher candidates is promising on behalf of the university that trains candidate physical education and sports teachers included in the sample. It may be suggested that this result be transferred to other universities as an example.

\section{REFERENCES}

[1] Alkın Ş.S., Tunca, N. \&Ulubey, Ö. (2014).The relationship between teacher candidates' educational beliefs and their critical thinking dispositions.Elementary Education Online, 13 (4), 1473-1492.

[2] Arslan, H.,\& Uslu, B. (2014). Examining the leadership orientations of teacher candidates. E-International Journal of Educational Research, 5 (1), 42-60.

[3] Beşoluk, Ş. \& Önder, İ. (2010). Examination of prospective teachers' approaches to learning, learning styles and critical thinking dispositions. Elementary Education Online, 9 (2), 679-693.

[4] Bulut, R. \& January, G. (2017). Investigation of the relationship between critical thinking disposition and learning strategies, Ahi Evran University Journal of Kırşehir Education Faculty, 18 (3) .1010-1031.

[5] Büyüköztürk, Ş., Çakmak, E. K., Akgün, Ö. E., Karadeniz, Ş., \& Demirel, F. (2017). Scientific research methods. Pegem Citation Index, 1-360.

[6] Bybee, R. W. (2010). Advancing STEM education: A 2020 vision. Technology and engineering teacher, $70(1), 30$.

[7] Can, Ş. \& Kaymakçı, G. (2015). Pre-service teachers' critical thinking dispositions, NWSA-Education Sciences, 10 (2), 66-83.

[8] Ennis, Robert H. (2011). Critical Thinking: Reflection And Perspective—Part I. Inquiry, Vol. 26, 1.

[9] Floyd, C. B. (2011). Critical thinking in a second language. Higher Education Research \& Development, 30(3),289-302.

[10] Fisher R. (1995). Teaching Children to Learn, Stanley Thornes.

[11] Güngör, N. B. (2016). Examining the relationship between epistemological beliefs and leadership traits of physical education teacher candidates. Unpublished master's thesis. Gazi University, Faculty of Education, Ankara. 
Are Critical Thinking Tendencies of the Physical Education Teacher Candidates Differ from Mathematics and Literature?

[12] Karalı, Y. (2012). Critical Thinking Tendencies of Education Faculty Students (Inönü University Example). Unpublished Master's Thesis, İnönü University Institute of Educational Sciences, Malatya.

[13] Kartal, T. (2012). Investigation of primary school science teacher candidates' critical thinking dispositions. Ahi Evran University Journal of Kırşehir Education Faculty, 13 (2), 279-297.

[14] Kawashima, N.,\& Shiomi, K. (2007). Factors of the thinking disposition of Japanese high school students. Social Behavior and Personality: an international journal, 35(2), 187-194.

[15] Kuvaç, M.,\& Koç, I. (2014). Critical thinking dispositions of pre-service science teachers: Istanbul University example. Turkish Journal of Education, 3 (2), 46-59.

[16] Leaver-Dunn, D., Harrelson, G. L., Martin, M., \& Wyatt, T. (2002). Critical-thinking predisposition among undergraduate athletic training students. Journal of Athletic Training, 37(4 suppl), S-147.

[17] Loken, L. M. (2005). Critical thinking abilities of undergraduate entry-level athletic training students. University of South Dakota.

[18] McBride, R., Xiang, P. ve Wittenburg, D. (2002). Dispositions Toward Critical Thinking: The Pre-service Teacher's Perspective, Teachers and Teach-ing: Theory and Practice, 8 (1), 29-40.

[19] Memduhoğlu, H. B. \& Keleş, E. (2016). Evaluation of the relation between critical-thinking tendency and problem-solving skills of pre-service teachers. Journal of Educational Sciences Research, 6(2), 75-94.

[20] Ocak, G., Eymir, E. \& Ocak, İ. (2016). Examination of pre-service teachers' critical thinking dispositions in terms of various variables.Erzincan University Journal of Education Faculty, 18 (1), 63-91.

[21] Ricketts, J. C. \& Rudd, R. (2004). Critical thinking skills of FFA leaders. Journal of Southern Agricultural Education Research, 54(1), 7-20.

[22] Rodriquez, G.D. (2000). Demographics and Disposition as Predictors of the Appli-cation of Critical Thinking Skills in Nursing Practice. Unpublished Doctoral Dissertation, Colorado State University. Fort Collins, CO.

[23] Ruff, L.G. (2005). The development of critical thinking skills and dispositions in firstyear college students: Infusing critical thinking instruction into a first-year transitions course (Doctoral dissertation, University of Maryland - College Park, 2005). Dissertations Abstracts International, 66(12).

[24] Sağlam, A. C.. and Büyükuysal, E. (2013). The critical thinking levels of the faculty of education class students and their views on the obstacles to this. International Journal of Human Sciences, 10 (1), 258278.

[25] Şenlik, N. Z., Balkan, Ö. and Aycan, Ş. (2011). Critical Thinking Skills of Teacher Candidates: The Case of Muğla University. C.B. Ü. Journal of Science, 7 (1), 67-76.

[26] Tekin, N., Aslan, O., \& Yağı, D. (2016). Examination of scientific literacy levels and critical thinking dispositions of pre-service science teachers. Amasya University Journal of Education, 5(1), 23-50.

[27] Thompson, M. C. (2001). Vocabulary and grammar: Critical content for critical thinking. Journal of secondary gifted education, 13(2), 60-66.

[28] Tümkaya, S. (2011). Investigation of science students' critical thinking dispositions and learning styles. Ahi Evran University Journal of Education Faculty, 12 (3), 215-234.

[29] Türnüklü, E. B. \& Yeşildere, S. (2005). A profile from Turkey: 11-13 age group trends and critical thinking skills of mathematics teacher candidates. Ankara University Faculty of Educational Sciences Journal, 38 (2), 167-185.

[30] Wangensteen, S., Johansson, I. S., Björkström, M. E., \& Nordström, G. (2010). Critical thinking dispositions among newly graduated nurses. Journal of advanced nursing, 66(10), 2170-2181.

[31] Zhang, H, \& Lambert, V. (2008). Critical thinking dispositions and learning styles of baccalaureate nursing students from China. Nursing Health Science, 10(3), 175-181.

Citation: Fatih ÖZGÜL. "Are Critical Thinking Tendencies of the Physical Education Teacher Candidates Differ from Mathematics and Literature?" International Journal of Sports and Physical Education (IJSPE), vol 6, no. 4, 2020, pp. 16-21. doi: https://doi.org/10.20431/2454-6380.0604004.

Copyright: (C) 2020 Authors. This is an open-access article distributed under the terms of the Creative Commons Attribution License, which permits unrestricted use, distribution, and reproduction in any medium, provided the original author and source are credited. 